\title{
Supplementation of a supranutritional dose of zinc sulfate and heat killed Bacillus firmus in early weanling pig diet: the effect on growth, neutrophil function and inflammatory cytokines
}

\author{
Ujjwal K. De ${ }^{1 *}$, Reena Mukherjee ${ }^{1}$, Gyanendra K. Gaur ${ }^{2}$, \\ Ashok K. Verma ${ }^{3}$, Sameer Shrivastava ${ }^{4}$, Chandan Prakash ${ }^{5}$, \\ Sukdeb Nandi ${ }^{6}$, and Med R. Verma ${ }^{7}$ \\ ${ }^{1}$ Division of Medicine, Indian Veterinary Research Institute, Izatnagar Uttar Pradesh, India \\ ${ }^{2}$ Livestock Production and Management Section, ICAR-Indian Veterinary Research Institute, Izatnagar, \\ Uttar Pradesh, India \\ ${ }^{3}$ Division of Animal Nutrition, ICAR-Indian Veterinary Research Institute, Izatnagar, Uttar Pradesh, India \\ ${ }^{4}$ Division of Veterinary Biotechnology, ICAR-Indian Veterinary Research Institute, Izatnagar, \\ Uttar Pradesh, India
}

${ }^{5}$ Division of Animal Health, ICAR-Central Sheep and Wool Research Institute, Avikanaga, Rajasthan, India ${ }^{6}$ CADRAD, ICAR-Indian Veterinary Research Institute, Izatnagar, Uttar Pradesh, India

${ }^{7}$ Division of Livestock Economics, Statistics and Information Technology, ICAR-Indian Veterinary Research Institute, Izatnagar, Uttar Pradesh, India

DE, U. K., R. MUKHERJEE, G. K. GAUR, A. K. VERMA, S. SHRIVASTAVA, C. PRAKASH, S. NANDI, M. R. VERMA: Supplementation of a supranutritional dose of zinc sulfate and heat killed Bacillus firmus in early weanling pig diet: the effect on growth, neutrophil function and inflammatory cytokines. Vet. arhiv 89, 529-543, 2019.

\section{ABSTRACT}

The objective of the study was to investigate the effect of supplementation of a supranutritional dose of zinc sulfate $\left(\mathrm{ZnSO}_{4}\right)$ and Bacillus firmus derived bio-response modifier (BRM) on growth, blood neutrophil functions, pro-inflammatory and anti-inflammatory cytokine responses in early weanling piglets. In total, 45 piglets (age of $19.25 \pm 0.84$ days) were randomly divided into five groups: I (basal diet only), II (basal diet supplemented with $\mathrm{ZnSO}_{4}$ ), III (basal diet supplemented with BRM), IV (basal diet supplemented with $\mathrm{ZnSO}_{4}$ plus BRM) and $\mathrm{V}$ (basal diet without weaning from dam). The production of myeloperoxidase (MPO) and superoxide anion $\left(\mathrm{O}_{2}^{-}\right)$, and the concentration of transforming growth factor- $\beta 1$ (TGF- $\beta 1$ ) were markedly reduced, whereas the concentrations of intercellular adhesion molecule 1 (ICAM1), and monocyte chemoattractant protein 1 (MCP1)

*Corresponding author:

Ujjwal K. De, Division of Medicine, ICAR-Indian Veterinary Research Institute, Izatnagar 243122 (Uttar Pradesh), India, E-mail: ujjwalde@gmail.com. 
U. K. De et al.: Effect of zinc sulfate and heat killed Bacillus firmus on growth and immunological response in weanling piglets

were significantly $(\mathrm{P}<0.05)$ increased in piglets during the post-weaning period. The neutrophil functions did not improve until day 7 of weaning $(\mathrm{P}>0.05)$ but a marked increase $(\mathrm{P}<0.05)$ in ICAM1, MCP1 and a decrease in TGF- $\beta 1$ concentrations were observed up to days 14 and 7, respectively, in piglets of groups II and III. However, the addition of BRM plus $\mathrm{ZnSO}_{4}$ in the basal diet improved MPO (day 2) and $\mathrm{O}_{2}^{-}$(day 7) without any significant alterations in growth and cytokine concentrations in group IV piglets. Finally, it is concluded that the addition of BRM plus $\mathrm{ZnSO}_{4}$ to the diet stimulates the innate immunity of weaner piglets compared to $\mathrm{ZnSO}_{4}$ or BRM alone. The findings of the study will definitely help to formulate effective dietary management practice for early weanling piglets in swine herds.

Key words: Bacillus firmus; cytokine; piglet; weaning; zinc sulfate

\section{Introduction}

Early weaning is one of the most important management practices in modern swine husbandry. The young piglets are abruptly forced to adapt to nutritional, immunological and psychological disturbances after weaning. In spite of several advantages, weaning induced physiological stress has some instant negative impacts on the immune system of the body and the structural and functional activities of the intestines. The notable immunological alterations include compromised function of immune cells and upregulation of pro-inflammatory cytokines, which in turn cause marked changes to the intestinal structure and function, leading to multiple infections and scouring after weaning (CAMPBELL et al., 2013; HU et al., 2013). Such changes are more severe at 2 to 5 days post-weaning, and it takes around 14 days post-weaning to recover (MEI and XU, 2005). The gut health of early weaned piglets is highly regulated by multiple growth factors and cytokines for restoration of damaged intestines (BLIKSLAGER et al., 2007). Among the various regulatory molecules, pro-inflammatory and anti-inflammatory cytokines help to maintain gut/intestinal health in early weaned piglets (CAMPBELL et al., 2013). The pro-inflammatory chemokines, such as intercellular adhesion molecule 1 (ICAM1) and monocyte chemoattractant protein 1 (MCP1), and anti-inflammatory cytokines, such as transforming growth factor- $\beta 1$ (TGF- $\beta 1$ ) secreted by the endothelial, and most immune cells, play a vital role in immune function. Up-regulation of ICAM-1 and MCP1 and down-regulation of TGF- $\beta$ have been observed in early weaning associated gut inflammatory reactions (WANG et al., 2008; XIAO et al., 2014; LIU, 2015). TGF- $\beta 1$ plays an important regulatory role in the post-weaning adaptation process of the intestine of the pig (MEI and XU, 2005). To minimize the health complications, medicated early weaning practices are often advocated in swine herds (CLARK et al., 1994). In that context, antibiotics are often added to the diet of weanling piglets to prevent infections and improve growth during the weaning transition (CROMWELL, 2002). Due to the mammoth demerits, many countries have either banned or are in the process of banning the use of antibiotics in pig diets as a routine method for promoting growth. One of the promising alternatives to antimicrobials could be the use of a bio-response modifier 
U. K. De et al.: Effect of zinc sulfate and heat killed Bacillus firmus on growth and immunological response in weanling piglets

(BRM) and micronutrients. The beneficial effects of a microbial derived BRM have been reported in neonatal swine health (SCHMIED et al., 2012). The peptidoglycan layer of the cell wall of Bacillus firmus has a significant role in immunomodulation (LAWRENCE and NAUCIE, 1998). The cell wall components of the Bacillus organism have been reported to stimulate both innate and adaptive immunity both in laboratory animals and human beings (PROKESOVA et al, 1994; ZANVIT et al, 2010). Among the micronutrients, zinc is a vital essential nutrient for many physiological functions of swine (RICHARDS et al., 2010). It has been reported that weaned pigs often suffer from zinc deficiency and this disturbs their innate immunity and increases susceptibility to pathogens (LI et al., 2006; RINK and GABRIEL, 2000; DAVIN et al., 2013). Therefore, supplementation of supranutritional doses of zinc is often practised to improve the health and performances of piglets during the critical period of post-weaning (NATIONAL RESEARCH COUNCIL, 1998; BRITISH SOCIETY OF ANIMAL SCIENCE, 2003). The beneficial effects of supranutritional doses of zinc and BRM have been evaluated separately in weaned piglets in this study. Here, we hypothesized that the combined effects of supranutritional doses of zinc and BRM might have a beneficial effect on the innate immune response in early weanling piglets. Therefore, an attempt has been made to assess the synergistic effect of supranutritional doses of zinc and BRM on performance, the antimicrobial defence of peripheral leukocytes, and pro-and-anti-inflammatory cytokines in early weanling piglets.

\section{Materials and methods}

Care and use of animals. The study was conducted on early weanling cross-bred piglets (Landrace $\times$ indigenous) from the institute's Swine Production Farm, and the protocol of the experiment was approved by the committee for the purpose of control and supervision of experiments for animals (CPCSEA), India.

Procurement of B. firmus and preparation of biological response modifier (BRM). Freeze-dried B. firmus was procured from the Microbial Type Culture Collection and Gene Bank (MTCC No: 7531), Institute of Microbial Technology, Chandigarh, India. The culture was revived in nutrient broth and 11.0 gram of bacterial mass was produced by sub culturing. The total viable bacterial count was measured by the standard plate count method and the total bacterial cells were done by the nephelometry turbidity method. In the current study, the total viable bacterial count was $10^{10}$ colony-forming units $(\mathrm{cfu}) / \mathrm{mL}$ and the total cell count was $10^{12} / \mathrm{mL}$. The bacterial mass was heat killed at $100{ }^{\circ} \mathrm{C}$ for 30 minutes; non-viability of bacteria was confirmed by a sterility test. The killed bacterial mass was delipided by chloroform-ethanol (2:1) treatment, freeze dried and stored at -20 ${ }^{\circ} \mathrm{C}$ (LOMAKOVA et al., 2006). The delipidated $B$. firmus was termed as the bio-response modifier (BRM). 
U. K. De et al.: Effect of zinc sulfate and heat killed Bacillus firmus on growth and immunological response in weanling piglets

Diets and experimental protocol. All diets were based on a dry, basal diet and its composition is depicted in Table 1. The basal diet was formulated according to the NRC (1998), to fulfill the standard nutritional requirement of piglets weighing 4-6 kg. Additional benefits were evaluated after inclusion of BRM and higher Zn nutritional supplementation in the basal diet. The second diet was $\mathrm{Zn}$-enriched and consisted of the control diet mixed with $2000 \mathrm{mg} \mathrm{ZnSO}_{4} / \mathrm{kg}$ of feed. The third diet was a BRM-enriched diet that consisted of the control diet mixed with $100 \mathrm{mg} \mathrm{BRM} / \mathrm{kg}$ of feed, and the fourth diet was a $\mathrm{Zn}$ plus BRM-enriched diet that consisted of the control diet mixed with both $2000 \mathrm{mg} \mathrm{ZnSO}{ }_{4}$ and $100 \mathrm{mg} \mathrm{BRM} / \mathrm{kg}$ of feed.

Table 1. Ingredients and chemical composition of basal diet

\begin{tabular}{|l|c|}
\hline Item & Basal diet \\
\hline Ingredient (\% as fed basis \\
\hline Wheat bran & 16.00 \\
\hline Crushed maize & 46.00 \\
\hline Deoiled soya bean cake & 30.00 \\
\hline Fish meal & 6.00 \\
\hline Vitamin and mineral mixture* & 1.20 \\
\hline Common salt & 0.80 \\
\hline Chemical composition (\% dry matter basis) \\
\hline Crude protein (CP) & \\
\hline Digestible energy (kcal/kg) & 23.95 \\
\hline Organic matter & 3400.00 \\
\hline Ether extract & 92.73 \\
\hline Crude fiber & 2.40 \\
\hline Nitrogen free extract & 4.79 \\
\hline Total ash & 61.57 \\
\hline
\end{tabular}

*Per kilogram vitamin and mineral premix contained following compositions: Vitamin A 700000 IU; Vitamin D3 $70000 \mathrm{IU}$; Vitamin E $250 \mathrm{mg}$; Nicotinamide $1000 \mathrm{mg}$; cobalt $150 \mathrm{mg}$; Iodine $325 \mathrm{mg}$; Iron $1500 \mathrm{mg}$; Magnesium 6000 mg, Potassium 1000 mg, Sodium 5.9 mg; Sulfur 0.72\%; Zinc $9600 \mathrm{mg}$ and Calcium 25.5\% and Phosphorus, $12.75 \%$.

Cross-bred piglets (Landrace $\times$ indigenous) from the institute's experimental swine production farm were used in the present study. The piglets and dam were kept in the same farrowing pens with a concrete floor, and piglets were allowed to suck the dam's milk ad libitum until weaning. The overall management practices were identical for all piglets. A total of 45 cross-bred piglets (Landrace $\times$ indigenous), of both sexes, aged $19.25 \pm 0.84$ days, weighing 4-6 kg body weight, were randomly separated and assigned 
U. K. De et al.: Effect of zinc sulfate and heat killed Bacillus firmus on growth and immunological response in weanling piglets

to the control (group I), $\mathrm{ZnSO}_{4}$ (group II), $\mathrm{BRM}$ (group III) and $\mathrm{ZnSO}_{4}$ plus $\mathrm{BRM}$ (group IV) groups. Each group consisted of nine piglets, with individual piglets being used as the experimental unit. Another group, called Group V, consisting of nine piglets was kept with the dam and served as the unweaned control group. It received only the control diet. Feeding schedule was initiated 7 days before weaning and continued up to 14 days postweaning. The piglets were fed twice a day, with free access to water and feed. The piglets received no medication during the study period. The health of the piglets was examined daily by expert veterinarians, for any signs of disease or stress. The piglets were weighed 7 days before weaning (-7 day) and 14 days post-weaning.

\section{Assessment of peripheral neutrophil functions.}

Collection of blood samples. The blood samples (approximately, $6.0 \mathrm{~mL}$ ) were collected by venipuncture of the anterior vena cava into K3ethylenediaminetetraacetic acid (K3EDTA)-coated vacutainer tubes. Blood samples were collected before initiation of treatment (-7 day) and thereafter on days 2, 7 and 14 after weaning. After collection of blood, $2.0 \mathrm{~mL}$ blood was used for neutrophil isolation, and the rest of the samples were immediately centrifuged at $200 \mathrm{~g}$ for $10 \mathrm{~min}$ to separate plasma and stored at $-20^{\circ} \mathrm{C}$ until analysis.

Isolation of neutrophil. The neutrophils from the blood were separated following the method described by FIELD et al. (1985). Briefly, $2.0 \mathrm{~mL}$ blood samples were mixed with $2.0 \mathrm{~mL}$ phosphate buffered saline (PBS, $0.0132 \mathrm{M}, \mathrm{pH} 6.8 \pm 0.1$ ) and centrifuged at 1000 $\mathrm{g}$ for $15 \mathrm{~min}$ at room temperature to obtain packed red cells. The red cells were lysed by addition of $12 \mathrm{~mL}$ distilled water and the isotonicity was restored after $45 \mathrm{sec}$ by addition of $6 \mathrm{~mL}$ phosphate buffered $2.7 \% \mathrm{NaCl}$, and thoroughly mixed. After centrifugation at $125 \mathrm{~g}$ for $10 \mathrm{~min}$, the supernatant was removed and the cell pellet, consisting primarily of neutrophils, was re-suspended in Hanks Balanced Salt Solution (HBSS). The viability of cells was checked by the trypan blue exclusion technique, and purity was determined by differential leukocyte count. The cell numbers were adjusted to $1 \times 10^{6} / \mathrm{mL}$.

MPO activity. The concentrations of MPO in neutrophils were measured following the standard procedure (BRETZ and BAGGIOLINI, 1974), and enzyme concentration was calculated by using the molar extinction coefficient for oxidized $O$-dianisidine (Sigma, USA). The optical density (O.D.) value was measured at $560 \mathrm{~nm}$ in the spectrophotometer. The molar extinction coefficient for oxidized $O$-dianisidine was assayed with known amounts of glucose oxidase-peroxidase assay $(20,040 \pm 400)$.

$\mathrm{O}_{2}^{-}$production. The $\mathrm{O}_{2}^{-}$production of isolated neutrophils stimulated by phorbol-12myristate-13-acetate (PMA, $5 \mu \mathrm{g} / \mathrm{mL}$, Sigma, St Louis, MO, USA) was measured according to the method described by NAGAHATA et al. (1986). Briefly, the reaction mixture, consisting of $200 \mu \mathrm{L}$ of nitroblue tetrazolium solution $(0.1 \%$ NBT in Earle's Balanced Salt Solution), $200 \mu \mathrm{L}$ of $1 \times 10^{6}$ neutrophil $/ \mathrm{mL}$ and $25 \mu \mathrm{g}$ of PMA was prepared, 
U. K. De et al.: Effect of zinc sulfate and heat killed Bacillus firmus on growth and immunological response in weanling piglets

and the final volume $(440 \mu \mathrm{L})$ was adjusted with Earle's solution. After incubating at 37 ${ }^{\circ} \mathrm{C}$ for $30 \mathrm{~min}$, the reaction was stopped by adding $3.0 \mathrm{~mL}$ of $0.5(\mathrm{~N})$ Hydrochloric acid $(\mathrm{HCl})$, and centrifuged at $200 \mathrm{~g}$ for $5 \mathrm{~min}$. The cells were washed twice with $3.0 \mathrm{~mL}$ of $0.5(\mathrm{~N}) \mathrm{HCl}$ and resuspended in $3 \mathrm{~mL}$ of dimethyl formamide (DMF). Formazone was extracted by heating in a boiling water bath for $10 \mathrm{~min}$ and $2 \mathrm{~mL}$ of $10(\mathrm{~N})$ potassium hydroxide $(\mathrm{KOH})$ was added. The mixture was centrifuged (200 $\mathrm{g}$ for $5 \mathrm{~min}$.) at room temperature, and the optical density (OD) of the DMF layer was read at $710 \mathrm{~nm}$ using DMF as a blank. Delta OD $(\triangle \mathrm{OD})$ was calculated by subtracting resting OD from the OD stimulated by PMA. The results were expressed as $\mathrm{OD} / 1 \times 10^{6}$ neutrophils $/ 30 \mathrm{~min}$ in 3 $\mathrm{mL}$ of DMF.

Measurement of ICAM-1, MCP-1 and TGF- $\beta 1$ in plasma. The concentrations of ICAM-1 (ELISA kit for Intercellular Adhesion Molecule 1, Porcine (Pig), SEA548Po, Cloud-Clone Corp. USA, Uscn Life Science Inc.), MCP-1 (ELISA kit for Monocyte Chemotactic Protein 1,Porcine (Pig), SEA087Po, Cloud-Clone Corp. USA, Uscn Life Sciece Inc.) and TGF- $\beta 1$ (Quantikine ELISA Kit, TGF- $\beta 1$ Immunoassay, MB100B, R \& D System. Inc) in the plasma were measured using separate commercially available ELISA kits according to the manufacturer's instructions.

All the estimations described above were carried out before treatment ( -7 day) and thereafter on days 2, 7 and 14 of weaning.

Statistical analysis. The data were analyzed using the statistical package SAS v 9.3 (SAS Institute, Inc. 2011, Cary, NC, USA) to observe the effect of the independent diet variable on various neutrophil functions and pro-and anti-inflammatory cytokine markers. The data were taken repeatedly at different time intervals from each animal and analyzed using repeated measure ANOVA, with animal as the subject and period as the repeated measurement. For analyzing the effect of diets on myeloperoxidase activity, superoxide production and concentration of ICAM1, MCP1 and TGF- $\beta 1$, repeated measures ANOVA were applied using the following general linear model:

$Y_{i j k}=\mu+G_{i}+I D\left(G_{i}\right)+D_{j}+(G D)_{i j}+e_{i j k}$

Where

$Y_{i j k}=$ observed value of the response variable for $i^{\text {th }}$ group at $j-^{\text {th }}$ day

$\mu=$ general mean effect

$G_{i}=i{ }^{\text {th }}$ group effect

$I D\left(G_{i}\right)=$ animal within group (random term)

$D_{j}=$ effect of the $j^{- \text {th }}$ day

$e_{i j k}=$ error term 
U. K. De et al.: Effect of zinc sulfate and heat killed Bacillus firmus on growth and immunological response in weanling piglets

Multiple comparisons between groups, days and the interaction effects of i-th group and $\mathrm{j}$-th day were performed using the Tukey HSD test at 5\% level of significance. An individual pig was considered the experimental unit. A probability level (P) of 0.05 was selected as the statistical selection limit for all tests. The results are expressed as means and SEM.

\section{Results}

Health condition and body weight of piglets in response to diet supplementation. Clinically no illness was observed during the trial period, including post-weaning scours. The weight gain of piglets was calculated by taking weight values after 14 days of diet supplementation and subtracting the corresponding weight of each piglet at day -7 . The average weight gain during the 21 days study was $2.62 \pm 0.28 \mathrm{~kg}, 2.26 \pm 0.40 \mathrm{~kg}, 2.74$ $\pm 0.25 \mathrm{~kg}, 3.07 \pm 0.15 \mathrm{~kg}$ and $2.57 \pm 0.17 \mathrm{~kg}$ for groups I, II, III, IV and V respectively. Weanling piglets supplemented with either $\mathrm{ZnSO}_{4}(\mathrm{P}=0.41)$, $\mathrm{BRM}(\mathrm{P}=0.79)$ or $\mathrm{ZnSO}_{4}$ plus BRM $(\mathrm{P}=0.24)$ did not exhibit a statistically significant increase in body weight relative to piglets in the control diet groups.

Effect on peripheral neutrophil functions. A marked reduction of $\mathrm{O}_{2}^{-}$production and MPO activity was observed in weanling piglets (group I) compared to unweaned piglets (group V) receiving only the basal diet. Group II piglets (zinc enriched diet) did not exhibit any improvement in $\mathrm{O}_{2}^{-}$and MPO production in neutrophils on day $7(\mathrm{P}<0.05)$ and day $2(\mathrm{P}<0.05)$ of weaning, respectively, but an improvement was observed on day 14 for $\mathrm{O}_{2}^{-}$and day 7 onwards for MPO production. There was a significant improvement in $\mathrm{O}_{2}^{-}$ and MPO production by neutrophils in group II piglets (BRM enriched diet) on day 7 of weaning. The $\mathrm{ZnSO}_{4}$ plus BRM supplementation (group IV) did not alter MPO production statistically in piglets from the pre-weaning to the post-weaning period. Although $\mathrm{O}_{2}^{-}$ production significantly dropped on day 2 of weaning $(\mathrm{P}<0.05)$ an improvement was noted on day 7 and 14 of weaning. No statistically significant interaction $(\mathrm{P}<0.01)$ was observed between diet and $\mathrm{O}_{2}^{-}(\mathrm{P}=0.779)$ and $\mathrm{MPO}(\mathrm{P}=0.978)$ production by neutrophils (Table 2).

ICAM-1, MCP-1 and TGF 1 . The mean concentrations of ICAM- 1 and MCP-1 were markedly $(\mathrm{P}<0.05)$ increased, whereas the mean TGF $\beta 1$ concentration was significantly $(\mathrm{P}<0.05)$ decreased in the post-weaning period in the weaned piglets (group I). The mean ICAM-1 and MCP-1 concentrations remained persistently elevated, and the mean TGF $\beta 1$ concentration remained persistently lower in the post-weaning period in comparison with pre-weaning value in the zinc-enriched diet supplemented weanling piglets (group II). In the BRM supplemented piglets, the average ICAM-1, TGF $\beta 1$ and MCP- 1 concentrations reached towards pre-weaning values on days 14 and 7, respectively. Interestingly, the ICAM-1, MCP-1 and TGF $\beta 1$ concentrations did not differ significantly from the pre- 
U. K. De et al.: Effect of zinc sulfate and heat killed Bacillus firmus on growth and immunological response in weanling piglets

weaning to the post-weaning period in $\mathrm{ZnSO}_{4}$ and $\mathrm{BRM}$ supplemented piglets (group IV). Statistically no significant interaction was found between diet and concentrations of ICAM-1 $(\mathrm{P}=0.40)$, MCP-1 $(\mathrm{P}=0.60)$ and TGF $\beta 1(\mathrm{P}=0.21)($ Table 3$)$.

Table 2. Changes in the mean values of superoxide anion $\left(\mathrm{O}_{2} ;, \Delta \mathrm{OD} / 1 \times 10^{6} \mathrm{cells} / 3 \mathrm{~mL} \mathrm{DMF}\right)$ and myeloperoxidase (MPO, $\mu$ moles $/ 1 \times 10^{6}$ cells) production by peripheral blood neutrophils in response to supplementation with $\mathrm{ZnSO}_{4}$ (group II), $\mathrm{BRM}$ (group III), $\mathrm{ZnSO}_{4}$ plus BRM (group IV) and in control piglets (groups I and V).

\begin{tabular}{|c|c|c|c|c|c|c|c|}
\hline Groups & -7 day & 2 day & 7 day & 14 day & $\mathrm{T}$ & $\mathrm{S}$ & $\mathrm{T} \times \mathrm{S}$ \\
\hline \multicolumn{8}{|c|}{$\mathrm{O}_{2}^{-}\left(\Delta \mathrm{OD} / 1 \times 10^{6}\right.$ cells $/ 3 \mathrm{~mL}$ DMF $)$} \\
\hline Gr. I & $\begin{array}{c}0.230 \\
\pm 0.027^{\mathrm{a}, \mathrm{A}}\end{array}$ & $\begin{array}{c}0.105 \\
\pm 0.011^{\mathrm{b}, \mathrm{A}}\end{array}$ & $\begin{array}{c}0.145 \\
\pm 0.012^{\mathrm{b}, \mathrm{A}} \\
\end{array}$ & $\begin{array}{c}0.133 \\
\pm 0.021^{\mathrm{b}, \mathrm{A}} \\
\end{array}$ & \multirow{5}{*}{$<0.001$} & \multirow{5}{*}{$<0.001$} & \multirow{5}{*}{0.77} \\
\hline Gr. II & $\begin{array}{c}0.228 \\
\pm 0.024^{\mathrm{a}, \mathrm{A}}\end{array}$ & $\begin{array}{c}0.112 \\
\pm 0.012^{\mathrm{b}, \mathrm{A}}\end{array}$ & $\begin{array}{c}0.144 \\
\pm 0.019^{\mathrm{b}, \mathrm{A}}\end{array}$ & $\begin{array}{c}0.215 \\
\pm 0.036^{\mathrm{a}, \mathrm{A}}\end{array}$ & & & \\
\hline Gr. III & $\begin{array}{c}0.232 \\
\pm 0.025^{\mathrm{a}, \mathrm{A}}\end{array}$ & 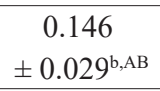 & $\begin{array}{c}0.164 \\
\pm 0.033^{\mathrm{a}, \mathrm{A}}\end{array}$ & $\begin{array}{c}0.204 \\
\pm 0.034^{\mathrm{a}, \mathrm{A}} \\
\end{array}$ & & & \\
\hline Gr. IV & $\begin{array}{c}0.234 \\
\pm 0.016^{\mathrm{a}, \mathrm{A}}\end{array}$ & $\begin{array}{c}0.193 \\
\pm 0.026^{\mathrm{b}, \mathrm{B}}\end{array}$ & $\begin{array}{c}0.198 \\
\pm 0.035^{\mathrm{a}, \mathrm{A}}\end{array}$ & $\begin{array}{c}0.223 \\
\pm 0.033^{\mathrm{a}, \mathrm{A}}\end{array}$ & & & \\
\hline Gr. V & $\begin{array}{c}0.232 \\
\pm 0.025^{\mathrm{a}, \mathrm{A}} \\
\end{array}$ & $\begin{aligned} & 0.205 \\
& \pm 0.025^{\mathrm{a}, \mathrm{AB}} \\
&\end{aligned}$ & $\begin{array}{c}0.215 \\
\pm 0.027^{\mathrm{a}, \mathrm{A}} \\
\end{array}$ & $\begin{array}{c}0.204 \\
\pm 0.034^{\mathrm{a}, \mathrm{A}} \\
\end{array}$ & & & \\
\hline \multicolumn{8}{|c|}{ MPO (MPO, $\mu$ moles $/ 1 \times 10^{6}$ cells $)$} \\
\hline Gr. I & $\begin{array}{l}3.64 \\
\pm 0.41 \mathrm{a}, \mathrm{A}\end{array}$ & $\begin{aligned} & 1.94 \\
\pm & 0.37^{\mathrm{b}, \mathrm{A}}\end{aligned}$ & $\begin{aligned} & 2.20 \\
\pm & 0.30^{\mathrm{b}, \mathrm{A}}\end{aligned}$ & $\begin{aligned} & 2.51 \\
& \pm 0.31 \mathrm{~b}, \mathrm{~A} \\
&\end{aligned}$ & \multirow{5}{*}{$<0.001$} & \multirow{5}{*}{$<0.001$} & \multirow{5}{*}{$0.9^{\prime}$} \\
\hline Gr. II & $\begin{aligned} & 3.58 \\
\pm & 0.38^{\mathrm{a}, \mathrm{A}}\end{aligned}$ & $\begin{aligned} & 2.02 \\
& \pm 0.21^{\mathrm{b}, \mathrm{A}} \\
&\end{aligned}$ & $\begin{aligned} & 2.40 \\
\pm & 0.39 \mathrm{a}, \mathrm{A}\end{aligned}$ & $\begin{aligned} & 2.63 \\
& \pm 0.29^{\mathrm{a}, \mathrm{A}} \\
&\end{aligned}$ & & & \\
\hline Gr. III & $\begin{array}{c}3.66 \\
\pm 0.35 \text { a,A }\end{array}$ & $\begin{array}{c}2.44 \\
\pm 0.37^{\mathrm{b}, \mathrm{AB}}\end{array}$ & $\begin{array}{c}2.81 \\
\pm 0.34 \text { a,A }\end{array}$ & $\begin{aligned} & 2.85 \\
\pm & 0.32^{\mathrm{a}, \mathrm{A}}\end{aligned}$ & & & \\
\hline Gr. IV & $\begin{array}{c}3.64 \\
\pm 0.52^{\mathrm{a}, \mathrm{A}}\end{array}$ & $\begin{array}{c}3.38 \\
\pm 0.47^{\mathrm{a}, \mathrm{B}}\end{array}$ & $\begin{array}{c}3.43 \\
\pm 0.48^{\mathrm{a}, \mathrm{A}}\end{array}$ & $\begin{array}{c}3.61 \\
\pm 0.50^{\mathrm{a}, \mathrm{A}}\end{array}$ & & & \\
\hline Gr. V & $\begin{array}{c}3.72 \\
\pm 0.62 \mathrm{a} \text { a,A }\end{array}$ & $\begin{aligned} & 3.18 \\
\pm & 0.63^{\mathrm{a}, \mathrm{B}}\end{aligned}$ & $\begin{array}{c}3.72 \\
\pm 0.62 \mathrm{a} \text { a,A }\end{array}$ & $\begin{aligned} & 3.23 \\
\pm & 0.35^{\mathrm{a}, \mathrm{A}}\end{aligned}$ & & & \\
\hline
\end{tabular}

$\mathrm{T}$ - treatment, $\mathrm{S}$ - sampling time, $\mathrm{T} \times \mathrm{S}$ - treatment $\times$ sampling time. Superscripts with small letters $(\mathrm{a}, \mathrm{b})$ indicate comparison between the days $(\mathrm{P}<0.05)$, mean $\pm \mathrm{SE}$ differ significantly $(\mathrm{P}<0.05))$ from pre-weaning baseline value (day-7). Superscripts with capital letters (A, B) indicate comparison between the groups $(\mathrm{P}<0.05)$, mean \pm $\mathrm{SE}$ differ by $\mathrm{P}<0.05$. Group or day with common letters do not differ significantly at $\mathrm{P}<0.05$. 
U. K. De et al.: Effect of zinc sulfate and heat killed Bacillus firmus on growth and immunological response in weanling piglets

Table 3. Changes in the mean concentration of $\operatorname{ICAM}^{-1}(\mathrm{ng} / \mathrm{dL}), \mathrm{MCP}^{-1}(\mathrm{ng} / \mathrm{mL})$ and TGF $\beta 1$ (pg/ $\mathrm{mL}$ ) in blood plasma in response to supplementation with $\mathrm{ZnSO}_{4}$ (group II), BRM (group III), $\mathrm{ZnSO}_{4}$ plus BRM (group IV) and in control piglets (groups I and V).

\begin{tabular}{|c|c|c|c|c|c|c|c|}
\hline Groups & -7 day & 2 day & 7 day & 14 day & $\mathrm{T}$ & $\mathrm{S}$ & $\mathrm{T} \times \mathrm{S}$ \\
\hline \multicolumn{8}{|c|}{ ICAM-1 (ng/dL) } \\
\hline Gr. I & $\begin{array}{c}739.25 \\
\pm 58.22^{\mathrm{a}, \mathrm{A}} \\
\end{array}$ & $\begin{array}{c}1112.57 \\
\pm 25.64^{\mathrm{b}, \mathrm{A}}\end{array}$ & $\begin{array}{c}1076.56 \\
\pm 28.94 \mathrm{~b}, \mathrm{~A} \\
\end{array}$ & $\begin{array}{c}1078.66 \\
\pm 34.53 \mathrm{~b}, \mathrm{~A} \\
\end{array}$ & \multirow{5}{*}{$<0.001$} & \multirow{5}{*}{$<0.001$} & \multirow{5}{*}{0.40} \\
\hline Gr. II & $\begin{array}{c}717.01 \\
\pm 89.42^{\mathrm{a}, \mathrm{A}}\end{array}$ & $\begin{array}{c}1091.24 \\
\pm 33.17 \mathrm{~b}, \mathrm{~A}\end{array}$ & $\begin{array}{c}1032.13 \\
\pm 37.45^{\mathrm{b}, \mathrm{A}}\end{array}$ & $\begin{aligned} & 967.05 \\
\pm & 61.66^{\mathrm{b}, \mathrm{AB}}\end{aligned}$ & & & \\
\hline Gr. III & $\begin{array}{c}713.85 \\
\pm 73.03^{\mathrm{a}, \mathrm{A}}\end{array}$ & $\begin{array}{c}962.83 \\
\pm 67.07 \mathrm{~b}, \mathrm{~A}\end{array}$ & $\begin{array}{c}966.46 \\
\pm 62.14 \mathrm{~b}, \mathrm{~B}\end{array}$ & $\begin{array}{c}769.10 \\
\pm 54.45^{\mathrm{a}, \mathrm{B}}\end{array}$ & & & \\
\hline Gr. IV & $\begin{array}{c}726.43 \\
\pm 92.79^{\mathrm{a}, \mathrm{A}}\end{array}$ & $\begin{array}{c}770.43 \\
\pm 81.38^{\mathrm{a}, \mathrm{B}}\end{array}$ & $\begin{array}{c}783.28 \\
\pm 117.76^{\mathrm{a}, \mathrm{BC}} \\
\end{array}$ & $\begin{array}{c}762.65 \\
\pm 75.30^{\mathrm{a}, \mathrm{B}} \\
\end{array}$ & & & \\
\hline Gr. V & $\begin{array}{c}720.36 \\
\pm 97.50^{\mathrm{a}, \mathrm{A}} \\
\end{array}$ & $\begin{array}{c}762.80 \\
\pm 92.28^{\mathrm{a}, \mathrm{B}} \\
\end{array}$ & $\begin{array}{c}728.54 \\
\pm 86.80^{\mathrm{a}, \mathrm{C}} \\
\end{array}$ & $\begin{array}{c}763.13 \\
\pm 91.95^{\mathrm{a}, \mathrm{B}} \\
\end{array}$ & & & \\
\hline \multicolumn{8}{|c|}{ MCP-1 (ng/mL) } \\
\hline Gr. I & $\begin{aligned} & 1.71 \\
\pm & 0.19^{\mathrm{a}, \mathrm{A}}\end{aligned}$ & $\begin{aligned} & 2.46 \\
& \pm 0.14^{\mathrm{b}, \mathrm{A}} \\
&\end{aligned}$ & $\begin{aligned} & 2.66 \\
& \pm 0.28^{\mathrm{b}, \mathrm{A}} \\
&\end{aligned}$ & $\begin{aligned} & 2.57 \\
\pm & 0.18^{\mathrm{b}, \mathrm{A}}\end{aligned}$ & \multirow{5}{*}{$<0.001$} & \multirow{5}{*}{$<0.001$} & \multirow{5}{*}{0.60} \\
\hline Gr. II & $\begin{aligned} & 1.66 \\
\pm & 0.12^{\mathrm{a}, \mathrm{A}}\end{aligned}$ & $\begin{aligned} & 2.52 \\
\pm & 0.28^{\mathrm{b}, \mathrm{B}}\end{aligned}$ & $\begin{aligned} & 2.49 \\
\pm & 0.22^{\mathrm{b}, \mathrm{A}}\end{aligned}$ & $\begin{aligned} & 2.68 \\
\pm & 0.33^{\mathrm{b}, \mathrm{A}}\end{aligned}$ & & & \\
\hline Gr. III & $\begin{array}{c}1.708 \\
\pm 0.21 \mathrm{a}, \mathrm{A}\end{array}$ & $\begin{aligned} & 2.51 \\
\pm & 0.15^{\mathrm{b}, \mathrm{B}}\end{aligned}$ & $\begin{aligned} & 1.98 \\
\pm & 0.30^{\mathrm{a}, \mathrm{A}}\end{aligned}$ & $\begin{aligned} & 1.92 \\
\pm & 0.25^{\mathrm{a}, \mathrm{A}}\end{aligned}$ & & & \\
\hline Gr. IV & $\begin{aligned} & 1.71 \\
& \pm 0.23^{\mathrm{a}, \mathrm{A}} \\
&\end{aligned}$ & $\begin{array}{c}1.86 \\
\pm 0.22^{\mathrm{a}, \mathrm{AB}} \\
\end{array}$ & $\begin{aligned} & 1.77 \\
\pm & 0.42^{\mathrm{a}, \mathrm{A}}\end{aligned}$ & $\begin{aligned} & 1.78 \\
\pm & 0.29 \mathrm{a}, \mathrm{A}\end{aligned}$ & & & \\
\hline Gr. V & $\begin{aligned} & 1.77 \\
& \pm 0.12^{\mathrm{a}, \mathrm{A}} \\
&\end{aligned}$ & $\begin{array}{c}1.79 \\
\pm 0.25^{\mathrm{a}, \mathrm{AB}} \\
\end{array}$ & $\begin{aligned} & 1.72 \\
& \pm 0.36^{\mathrm{a}, \mathrm{A}} \\
&\end{aligned}$ & $\begin{aligned} & 1.85 \\
& \pm 0.25^{\mathrm{a}, \mathrm{A}} \\
&\end{aligned}$ & & & \\
\hline \multicolumn{8}{|c|}{ TGF $\beta 1(\mathrm{pg} / \mathrm{mL})$} \\
\hline Gr. I & $\begin{array}{c}119.36 \\
\pm 4.24 \mathrm{a}, \mathrm{A}\end{array}$ & $\begin{array}{c}72.34 \\
\pm 4.92 \mathrm{~b}, \mathrm{~A}\end{array}$ & $\begin{aligned} & 78.52 \\
\pm & 10.86^{\mathrm{b}, \mathrm{A}}\end{aligned}$ & $\begin{array}{c}97.17 \\
\pm 8.05^{\mathrm{b}, \mathrm{A}}\end{array}$ & \multirow{5}{*}{$<0.001$} & \multirow{5}{*}{$<0.001$} & \multirow{5}{*}{0.21} \\
\hline Gr. II & $\begin{array}{c}115.36 \\
\pm 6.566^{\mathrm{a}, \mathrm{A}}\end{array}$ & $\begin{aligned} & 88.10 \\
\pm & 7.42^{\mathrm{b}, \mathrm{AB}}\end{aligned}$ & $\begin{array}{c}84.33 \\
\pm 7.19^{\mathrm{b}, \mathrm{A}}\end{array}$ & $\begin{array}{c}89.39 \\
\pm 7.89^{\mathrm{a}, \mathrm{A}}\end{array}$ & & & \\
\hline Gr. III & $\begin{array}{c}117.75 \\
\pm 9.27 \mathrm{a}, \mathrm{A}\end{array}$ & $\begin{array}{c}85.28 \\
\pm 9.04 \mathrm{~b}, \mathrm{AB}\end{array}$ & $\begin{aligned} & 90.30 \\
\pm & 9.82 \mathrm{~b}, \mathrm{AB}\end{aligned}$ & $\begin{array}{c}108.17 \\
\pm 2.98^{\mathrm{a}, \mathrm{A}}\end{array}$ & & & \\
\hline Gr. IV & $\begin{array}{c}120.42 \\
\pm 3.80^{\mathrm{a}, \mathrm{A}}\end{array}$ & $\begin{array}{c}104.79 \\
\pm 5.26^{\mathrm{a}, \mathrm{BC}}\end{array}$ & $\begin{array}{c}111.92 \\
\pm 5.39 \mathrm{a}, \mathrm{BC}\end{array}$ & $\begin{array}{c}106.22 \\
\pm 8.41^{\mathrm{a}, \mathrm{A}}\end{array}$ & & & \\
\hline Gr. V & $\begin{array}{c}118.20 \\
\pm 6.63 \mathrm{a} \text { a, }\end{array}$ & $\begin{array}{l}114.00 \\
\pm 5.96^{\mathrm{a}, \mathrm{C}}\end{array}$ & $\begin{array}{c}116.84 \\
\pm 5.56^{\mathrm{a}, \mathrm{C}}\end{array}$ & $\begin{array}{c}110.63 \\
\pm 4.36^{\mathrm{a}, \mathrm{A}}\end{array}$ & & & \\
\hline
\end{tabular}

$\mathrm{T}$ - treatment, $\mathrm{S}$ - sampling time, $\mathrm{T} \times \mathrm{S}$ - treatment $\times$ sampling time. Superscripts with small letters $(\mathrm{a}, \mathrm{b})$ indicate comparison between the days $(\mathrm{P}<0.05)$, mean $\pm \mathrm{SE}$ differ significantly $(\mathrm{P}<0.05))$ from pre-weaning baseline value (day-7). Superscripts with capital letters (A, B, C ) indicate comparison between the groups $(\mathrm{P}<0.05)$, mean \pm SE differ by $\mathrm{P}<0.05$. Group or day with common letters do not differ significantly at $\mathrm{P}<0.05$.

Vet. arhiv 89 (4), 529-543, 2019 
U. K. De et al.: Effect of zinc sulfate and heat killed Bacillus firmus on growth and immunological response in weanling piglets

\section{Discussion}

Early weaned piglets are more prone to multiple infections due to compromised immunity, resulting in high morbidity and mortality in the post-weaning period. Therefore, boosting the innate immunity of weaned piglets in this critical period would be a favorable option to minimize the undesirable stress conditions. In the present study, we found the decreased functional capacity of peripheral blood neutrophils after the early weaning of piglets, and the findings are in accordance with previous workers (WATTRANG et al., 1998; HAN et al., 2014). In the current study, although the supranutritional level of $\mathrm{ZnSO}_{4}$ supplementation did not improve the $\mathrm{O}_{2}^{-}$production and MPO activity of peripheral neutrophils until day 7, a significant enhancement was noted on day 14 of weaning. Zinc is an essential micronutrient having an important role in revitalizing impaired immune functions (RINK and GABRIEL, 2000). It has been reported that supranutritional supplementation of zinc enhances non-specific innate immunity through natural killer cell activity, chemotaxis, phagocytosis, generation of the oxidative burst, and cytokine response in newly weaned piglets (KIM et al., 2009; LIU et al., 2014). In our study, improvement of the neutrophil function might have been due to the immunomodulatory potential of zinc sulfate. The B. firmus derived BRM supplementation significantly improved the $\mathrm{O}_{2}^{-}$production and MPO activity of neutrophils from day 7 onwards. The enhanced activity of neutrophil function indicates the immunomodulatory potential of $B$. firmus derived BRM. LOMAKOVA et al. (2006) reported that delipidated B. firmus (DBF) activates peritoneal macrophages in mice through cytokine activity. Further, DBF has been reported to be a very potent adjuvant to stimulate innate immunity after intranasal immunization with inactivated influenza virus type A in a mouse model (ZANVIT et al., 2010).

The ICAM-1 and MCP-1 are pro-inflammatory chemokines and TGF- $\beta$ is an antiinflammatory cytokine. In the present study, the persistent elevation of ICAM-1and MCP-1 concentration and the marked $(\mathrm{P}<0.05)$ decrease in TGF $\beta 1$ concentration in piglets during the post-weaning period might be due to inflammatory responses (LIU, 2015; XIAO et al., 2014). Although we did not measure the concentrations of ICAM-1, MCP-1 and TGF- $\beta$ in the intestinal compartment, the alteration of these molecules in the peripheral circulation might be due to systemic inflammatory reaction following early weaning (McCRACKEN et al., 1999; GAO et al., 2011). Alterations in cytokines due to gut starvation affect systemic inflammatory responses besides the mucosal immune system. The upregulation of pro-inflammatory cytokines increases intestinal epithelial permeability and regulates the immune functions, whereas anti-inflammatory cytokines protect against intestinal inflammation by preserving the barrier function (HOWE et al., 2005; AL-SADI et al., 2009; CAMPBELL et al., 2013). Moreover, activation of the immune system in piglets during weaning causes gut upset and reduced feed intake. Here, 
U. K. De et al.: Effect of zinc sulfate and heat killed Bacillus firmus on growth and immunological response in weanling piglets

supranutritional zinc supplementation was not able to reduce the ICAM-1 and MCP-1 concentrations in the post-weaning period. However, the concentration of TGF $\beta 1$ was significantly $(\mathrm{P}<0.05)$ increased on day 14 of post-weaning, which might be due to the restoration of the integrity of the intestinal barrier, as TGF-b1 is believed to play a regulatory role in the post-weaning adaptation process of the intestines in pigs (MEI and $\mathrm{XU}, 2005$ ). HU et al. (2013) observed increased mRNA levels of TGF- $\beta$ and IL-10 in high zinc diet supported post-weaning piglets. In BRM supplemented piglets, the ICAM1 and MCP-1 concentrations initially increased significantly $(\mathrm{P}<0.05)$ on day 3 postweaning, and thereafter the values decreased towards the pre-weaning value on days 14 and 7 respectively. The concentration of TGF $\beta 1$ improved significantly $(\mathrm{P}<0.05)$ on day 14 post-weaning. The initially increased concentrations of ICAM-1 and MCP-1 might be due to cytokines secreted from inflammatory cells in response to B. firmus derived BRM (TAKAHASHI et al., 1995). The secretion of inflammatory cytokines from immune cells by the B. firmus derived BRM/ adjuvant was demonstrated by previous researchers in mouse models (LOMAKOVA et al., 2006; ZANVIT et al., 2010). In the present study, the production of $\mathrm{O}_{2}^{-}$and MPO by leukocytes, and the concentrations of ICAM-1, MCP-1 and TGF $\beta 1$ in the plasma did not differ significantly $(\mathrm{P}>0.05)$ between the pre- and postweaning periods in response to combined delipidated $B$. firmus and zinc supplementation in piglets. Peptidoglycan, derived from the cell wall of Bacillus spp. has been shown to have immunomodulatory properties, along with zinc, in immune-deficient mice models (HAYHURST et al., 2008 ; RAVLIC-GULAN et al., 2000). The responses of neutrophils and chemokines were much earlier under combined treatment than with $\mathrm{ZnSO}_{4}$ or BRM alone, and this might be due to synergistic effect or potentiation of the immunostimulant effect of BRM by $\mathrm{ZnSO}_{4}$.

The results of the present study indicate that supplementation of a supranutritional dose of Zinc sulfate and B. firmus derived BRM synergistically stimulated peripheral blood neutrophil functions, anti-inflammatory cytokine, and decreased the proinflammatory cytokines in early weanling piglets. It might be associated with immunomodulation and reduced inflammatory response in the post-weaning period. The findings of the study will definitely help to formulate effective dietary management practices for early weanling piglets in farm conditions.

\section{Conflicts of interest}

The authors declare they have no conflict of interest.

\section{Acknowledgements}

The authors gratefully acknowledge the financial support and facilities provided by the Director, IVRI, Izatnagar (UP, India) under the institute-funded research project. The help and support of the staff of the laboratory and Swine Production Farm is also acknowledged.

Vet. arhiv 89 (4), 529-543, 2019 
U. K. De et al.: Effect of zinc sulfate and heat killed Bacillus firmus on growth and immunological response in weanling piglets

\section{References}

AL-SADI, R., M. BOIVIN, T. MA (2009): Mechanism of cytokine modulation of epithelial tight junction barrier. Front. Biosci. 14, 2765-2778.

DOI: $10.2741 / 3413$

BLIKSLAGER, A. T., A. J. MOESER, J. L. GOOKIN, S. L. JONES, J. ODLE (2007): Restoration of barrier function in injured intestinal mucosa. Physiol. Rev. 87, 545-564.

DOI: $10.1152 /$ physrev.00012.2006

BRETZ, U., M. BAGGIOLINI (1974): Biochemical and morphological characterization of azurophilic and specific granules of human neutrophilic polymorphonuclear leucocytes. J. Cell Biol. 63, 251-269.

DOI: $10.1083 /$ jcb.63.1.251

BRITISH SOCIETY OF ANIMAL SCIENCE (2003): Nutrient requirement standards for pigs. $4^{\text {th }}$ rev. ed.. Penicuik, Midlothian, UK. p. 28

CAMPBELL, J. M., J. D. CRENSHAW, J. POLO (2013):. The biological stress of early weaned piglets. J. Anim. Sci. Biotechnol. 4, 19.

DOI: $10.1186 / 2049-1891-4-19$

CLARK, L. K., M. A. HILl, T. S. KNIFFEN, W. VANALSTINE, G. STEVENSON, K. B. MEYER, C. C. WU, A. B. SCHEIDT, K. KNOX, S. ALBREGTS (1994): An evaluation of the components of medicated early weaning. J. Swine Health Prod. 2, 5-11

CROMWELL, G. L. (2002): Why and how antibiotics are used in swine production. Anim. Biotechnol. 13, 7-27.

DOI: $10.1081 / \mathrm{ABIO}-120005767$

DAVIN, R., E. G. MANZANILLA, K. C. KLASING, J. F. PÉREZ (2013): Effect of weaning and in-feed high doses of zinc oxide on zinc levels in different body compartments of piglets. J. Anim. Physiol. Anim. Nutr. 97, 6-12.

DOI: 10.1111/jpn.12046

FIELD, T. R., M. R. WILLIAMS, K. J. BUNCH (1985): An improved method for the isolation of a neutrophil-rich fraction from porcine blood. Br. Vet. J. 141, 355-361.

DOI: 10.1016/0007-1935(85)90084-3

GAO, Y. Y., Z. Y. JIANG, Y. C. LIN, C. T. ZHENG, G. L. ZHOU, F. CHEN (2011): Effects of spray-dried animal plasma on serous and intestinal redox status and cytokines of neonatal piglets. J. Anim. Sci. 89, 150-157.

DOI: $10.2527 /$ jas.2010-2967

HAN, J., B. LIANQUAN, L. XIANJUN, F. ZHANG, Y. ZHANG, N. YU (2014): Effects of Acanthopanax senticosus polysaccharide supplementation on growth performance, immunity, blood parameters and expression of pro-inflammatory cytokines genes in challenged weaned piglets. Asian-Australas J. Anim. Sci. 27, 1035-1043.

DOI: 10.5713 ajas.2013.13659 
U. K. De et al.: Effect of zinc sulfate and heat killed Bacillus firmus on growth and immunological response in weanling piglets

HAYHURST, E. J., L. KAILAS, J. K. HOBBS, S. J. FOSTER (2008): Cell wall peptidoglycan architecture in Bacillus subtilis. Proc. Natl. Acad. Sci. USA, 105, 14603-14608.

DOI: 10.1073/pnas.0804138105

HOWE, K., C. REARDON, A. WANG, A. NAZLI, D. M. McKAY (2005): Transforming growth factor-beta regulation of epithelial tight junction proteins enhances barrier function and blocks enterohemorrhagic Escherichia coli O157:H7-induced increased permeability. Am. J. Pathol. $167,1587-1597$.

DOI: $10.1016 / \mathrm{s} 0002-9440(10) 61243-6$

HU, C. H., K., XIAO, J. SONG, Z. S. LUAN (2013): Effects of ZnO supported on zeolite on growth performance, intestinal microflora and permeability, and cytokines expression of weaned pigs. Anim. Feed Sci. Technol. 181, 65-71.

DOI: 10.1016/j.anifeedsci.2013.02.003

KIM, Y. J., J. H. KANG, M. P. YANG (2009): Zinc increases the phagocytic capacity of canine peripheral blood phagocytes in vitro. Vet. Res. Commun. 33, 251-261.

DOI: $10.1007 / \mathrm{s} 11259-008-9173-4$

LAWRENCE, C. C. NAUCIE (1998): Production of interleukin-12 by murine macrophages in response to bacterial peptidoglycan. Infect. Immun. 66, 4947-4949.

LI, X., J. YIN, D. LI, X. CHEN, J. ZANG, X. ZHOU (2006): Dietary supplementation with zinc oxide increases IGF-I and IGF-I receptor gene expression in the small intestine of weanling piglets. J. Nutr. 136, 1786-1791.

DOI: $10.1093 / \mathrm{jn} / 136.7 .1786$

LIU, P., R. PIEPER, J. RIEGER, W. VAHJEN, R. DAVIN, J. PLENDL, W. MEYER, J. ZENTEK (2014): Effect of dietary zinc oxide on morphological characteristics, mucin composition and gene expression in the colon of weaned piglets, PLoS One, 9, e91091.

DOI: 10.1371/journal.pone.0091091

LIU, Y. (2015): Fatty acids, inflammation and intestinal health in pigs. J. Anim. Sci. Biotechnol. 6,41 .

DOI: $10.1186 / \mathrm{s} 40104-015-0040-1$

LOMAKOVA, I., P. PETRASKOVA, I. STERZI, L. PROKESOVA (2006): Immunomodulatory effects of Bacillus firmus on mouse peritoneal cells in vitro. Folia Microbiol. 52, 243-247.

DOI: $10.1007 / \mathrm{bf02932130}$

McCRACKEN, B. A., M. E. SPURLOCK, M. A. ROOS, F. A. ZUCKERMANN, H. R. GASKINS (1999): Weaning anorexia may contribute to local inflammation in the piglet small intestine. J. Nutr. 129, 613-619.

DOI: $10.1093 / \mathrm{jn} / 129.3 .613$

MEI, J., R. J. XU (2005): Transient changes of transforming growth factor-b expression in the small intestine of the pig in association with weaning. Br. J. Nutr. 93, 37-45. DOI: $10.1079 /$ bjn20041302 
U. K. De et al.: Effect of zinc sulfate and heat killed Bacillus firmus on growth and immunological response in weanling piglets

NAGAHATA, H., A. YATSU, H. NODA (1986): The evaluation of a quantitative assay for estimating the bactericidal activity of bovine neutrophils by nitroblue tetrazolium reduction. Br. Vet. J. 142, 578-584.

DOI: $10.1016 / 0007-1935(86) 90117-\mathrm{x}$

NATIONAL RESEARCH COUNCIL (1998): Nutrient requirements of swine, $10^{\text {th }}$ rev. ed.. The National Academies Press, Washington, DC, USA. p. 57.

PROKESOVA, L., M. NOVAKOVA, J. JULAK, M. MARA (1994): Effect of Bacillus firmus and other sporulating aerobic microorganisms on in vitro stimulation of human lymphocytes. A comparative study. Folia Microbiol. 39, 501-504.

DOI: $10.1007 / \mathrm{bf02814071}$

RAVLIC-GULAN, J., B. RADOSEVIC-STASIC, G. GULAN, D. STIMAC, K. PAVELIC, D. RUKAVINA (2000): Immunoprotective properties of peptidoglycan monomer linked with zinc in cholestatic jaundice. Int. Arch. Allergy Immunol. 123, 354-64.

DOI: $10.1159 / 000053649$

RICHARDS, J. D., J. ZHAO, R. J. HARRELL, C. A. ATWELL, J. J. DIBNER (2010): Trace mineral nutrition in poultry and swine. Asian-Australas J. Anim. Sci. 23, 1527 - 1534

DOI: 10.5713/ajas.2010.r.07

RINK, L., P. GABRIEL (2000): Zinc and the immune system. Proc. Nutr. Soc. 59, 541-552. DOI: $10.1017 / \mathrm{S} 0029665100000781$

SCHMIED, J., P. RUPA, S. GARVIE, B. WILKIE (2012): Effect of heat-killed Escherichia coli, lipopolysaccharide, andmuramyl dipeptide treatments on the immune response phenotype and allergy in neonatal pigs sensitized to the egg white protein ovomucoid. Clin. Vac. Immunol. $19,1955-1964$.

DOI: 10.1128 /cvi.00555-12

TAKAHASHI, M., J. MASUYAMA, U. IKEDA, T. KASAHARA, S. KITAGAWA, Y. TAKAHASHI, K. SHIMADA, S. KANO (1995): Induction of monocyte chemoattractant protein-1 synthesis in human monocytes during transendothelial migration in vitro. Circ. Res. 76, 750-757.

DOI: $10.1161 / 01 . r e s .76 .5 .750$

WANG, J., L. CHEN, P. LI, X. LI, H. ZHOU, F. WANG, D. LI, Y. YIN, G. WU (2008): Gene expression is altered in piglet small intestine by weaning and dietary glutamine supplementation. J. Nutr. 138, 1025-1032.

DOI: $10.1093 /$ jn/138.6.1025

WATTRANG, E., P. WALLGREN, A. LINDBERG, C. FOSSUM (1998): Signs of infections and reduced immune functions at weaning of conventionally reared and specific pathogen free pigs. Zoonoses Public Hlth. 45, 7-17.

DOI: $10.1111 / j .1439-0450.1998 . t b 00760 . x$ 
U. K. De et al.: Effect of zinc sulfate and heat killed Bacillus firmus on growth and immunological response in weanling piglets

XIAO, K., Z. H. SONG, L. F. JIAO, Y. L. KE, C. H. HU (2014): Developmental changes of TGF-b1 and smads signaling pathway in intestinal adaption of weaned pigs. PLoS One. 9, e104589.

DOI: 10.1371/journal.pone.0104589

ZANVIT, P., A. TICHOPAD, M. HAVLICKOVA, O. NOVOTNA, M. JIRKOVSKA, K. KOlOSTOVA, D. CECHOVA, J. JULAKA, I. STERZL, L. PROKESOVA (2010): Adjuvant effect of Bacillus firmus on the expression of cytokines and toll-like receptors in mouse nasopharynx-associated lymphoid tissue (NALT) after intranasal immunization with inactivated influenza virus type A. Immunol. Lett. 134, 26-34.

DOI: $10.1016 /$ j.imlet.2010.08.006

Received: 4 March 2018

Accepted: 14 June 2019

\section{DE, U. K., R. MUKHERJEE, G. K. GAUR, A. K. VERMA, S. SHRIVASTAVA, C. PRAKASH, S. NANDI, M. R. VERMA: Dodatak supranutritivnih doza cinkova sulfata i bakterija Bacillus firmus ubijenih toplinom u obrok rano odbijenih svinja: utjecaj na rast, funkciju neutrofila i upalne citokine. Vet. arhiv 89, 529-543, 2019. \\ SAŽETAK}

Kod rano odbijene prasadi istražen je učinak dodavanja supranutritivnih doza cinkova sulfata $\left(\mathrm{ZnSO}_{4}\right)$ i modifikatora biološkog odgovora (BRM) izvedenog iz bakterija Bacillus firmus na rast, funkcije krvnih neutrofila te proupalni i protuupalni odgovor citokina. Ukupno 45 prasadi (u dobi 19,25 $\pm 0,84$ dana) nasumično je podijeljeno u pet skupina: I (samo osnovni obrok), II (osnovnom obroku dodan je $\mathrm{ZnSO}_{4}$ ), III (osnovnom obroku dodan je BRM), IV (osnovnom obroku dodan je $\mathrm{ZnSO}_{4}$ i BRM) i V (osnovni obrok kod neodbijene prasadi). Kod prasadi su nakon odbića znakovito sniženi proizvodnja mijeloperoksidaze (MPO), superoksidnog aniona $\left(\mathrm{O}_{2}^{-}\right)$i koncentracija transformacijskog čimbenika rasta- $\beta 1$ (TGF- $\left.\beta 1\right)$, a koncentracije međustanične adhezijske molecule-1 (ICAM1) i monocitnog kemoatraktanta protein - 1 (MCP1) znakovito su povišene $(\mathrm{P}<0,05)$. Funkcije neutrofila nisu poboljšane do 7 . dana od odbića $(\mathrm{P}>0,05)$, ali kod prasadi iz skupine II. i III. je 14. i 7. dana opaženo znakovito povišenje $(\mathrm{P}<0,05)$ ICAM1, MCP1, te sniženje koncentracije TGF- $\beta 1$. U

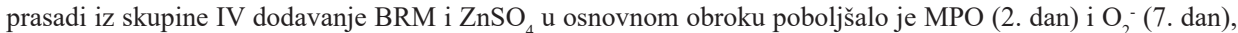
bez znakovitih promjena u rastu i koncentraciji citokina. Na kraju, zaključeno je da dodavanje kombinacije $\mathrm{BRM} \mathrm{i} \mathrm{ZnSO}_{4}$ u obroku potiče urođenu imunost prasadi što nije slučaj kada se $\mathrm{ZnSO}_{4}$ ili BRM dodaju zasebno. Rezultati ovog istraživanja pomoći će u formuliranju učinkovitog upravljanja hranidbom kod rano odbijene prasadi u krdu svinja.

Ključne riječi: Bacillus firmus; citokin; prasad; odbiće; cinkov sulfat 
